\title{
Democratizing International Law
}

\author{
Robert E. Goodin \\ Australian National University and University of Essex \\ Steven R. Ratner \\ University of Michigan
}

\section{Abstract}

Jus cogens are peremptory norms of international law. No treaty between states can violate them. They are based on fundamental moral precepts and are supposed to reflect a global consensus. As a result, the views of the people of the world - not just states and courts and international lawyers - ought to be assessed as part of that. Direct democratic input into what should be considered jus cogens can be promoted by convening Global Citizens' Juries on the norms under discussion. Deliberations in small groups of people drawn from many nations can provide robust indicators of what world opinion would be, if everyone had access to similar information and discussions. Where broad consensus emerges across several such Global Citizens' Juries, countries, courts and others ought to take that into account in deciding what to treat as peremptory norms of international law. Such a process would mark a significant contribution to improving the democratic deficit that currently prevails in making and implementing international law.

\section{Policy Implications}

- International law in general suffers from a democratic deficit, lacking any direct democratic input.

- The problem is particularly acute for peremptory norms of international law, those 'super-norms' that trump even treaties, which are supposed to reflect a global consensus concerning fundamental moral values.

- Global Citizens' Juries with people from many nations could test whether the norms under discussion would indeed command such a consensus.

- Widespread endorsement of a norm by Global Citizens' Juries would suggest that it should be regarded as a peremptory norm of international law.

- The result would lend more legitimacy to these norms than is achieved by mere governmental endorsement and, ultimately, promote greater respect for them.

International law is largely made by states. They sign treaties. They develop customs that become binding as law, at least on those states that did not persistently object. They recognize certain norms of international law as peremptory or jus cogens, from which no state is permitted to derogate.

Much of this proceeds without any direct input from the people of the world. True, there is indirect civil society input through NGOs (Boyle and Chinkin, 2007; Raustiala, 1997). True, also, many treaties are approved by legislatures. But those bodies are often not fairly elected, and in any case many treaties and customs enter into force without parliamentary action. Furthermore, treaty regimes can create institutions that are empowered to devise new rules and resolve disputes between states, or between states and investors or individuals - in a binding way without further popular involvement.
That democratic deficit in international lawmaking is a source of consternation to critics across the political spectrum. Critics from the left protest that the World Trade Organization and investment treaty regimes subject people around the world to rules and arbitral decisions without their own direct consent. Critics from the right protest at the prospect of democratically made domestic law being preempted by international human rights law, which is made and interpreted by international bodies that do not have any particularly strong democratic mandate themselves and that do not defer enough to the state's domestic values.

We offer one modest proposal to ameliorate those worries about the democratic deficit in international law. For reasons we shall elaborate, our proposal targets one special category of law, jus cogens. That is defined, in the words of the most authoritative text, as 'a norm accepted and recognized by the international community 
of states as a whole as a norm from which no derogation is permitted and which can be modified only by a subsequent norm of general international law having the same character' (Vienna Convention on the Law of Treaties, 1969, art. 53). These norms are particularly important because they place an impassable barrier to what states are legally allowed to do. No state, on its own or with the consent of others, is legally allowed to violate jus cogens.

Jus cogens is a sort of 'higher law' internationally that trumps other sorts of international law in cases of conflict. As key international players have recognized, jus cogens norms express some notion of international morality or public policy (Verdross, 1937, p. 574). As Bruno Simma (1994, pp. 229, 292) puts it, jus cogens reflects values 'which are not at the disposal of individual States (any more)'.

That jus cogens norms are an expression of core norms of international order and ethics is why they transcend state consent, and why they can limit what can be in a treaty. ('A treaty is void if ... it conflicts with a peremptory norm of general international law' under the Vienna Convention (1969, art. 53).) For the same reason, jus cogens norms are deemed obligations erga omnes, of interest to the community as a whole, thus opening the door to enforcement by third-party states (Frowein, 2008).

It is sometimes hard to see the impact of a norm's status as jus cogens (as opposed to an ordinary treaty or customary law rules) on actual state behavior, since lawabiding states do not come close to breaching them. But for states more prone to flouting the rules, violations of jus cogens are registered by more actors and typically come at a higher cost.

Substantively, what is included in jus cogens? A few states (France, conspicuously) have rejected the concept altogether in so far as it suggests a limit on a state's freedom. Most states and scholars would agree on a short list of rules that have reached the status of jus cogens: bans on the use of force, torture, genocide, crimes against humanity, racial discrimination and slavery; and the supremacy of the UN Charter over other treaties. But after that, we see disagreement. Some states and scholars would also include: the right of peoples to self-determination; many human rights found in the international covenants; and core elements of the Geneva Conventions on the rules of war. Some developing countries, NGOs and scholars go so far as to suggest that jus cogens would be violated by investment agreements between states or between states and foreign companies that give those companies significant rights in a host state.

Procedurally, how is it currently decided what is jus cogens? Ultimately, according to the definition quoted above, states and states alone determine its content. Yet at the same time, there is already some acknowledg- ment that states are not the only actors involved in jus cogens norms becoming recognized as internationally binding. The International Court of Justice (ICJ) has offered its views on the content of jus cogens, most recently in its judgment on Bosnia's suit against Serbia for genocide; so have other international courts (ICJ, 2007a, para. 161). And the ICJ itself is instructed under its statute to inspect not only state action through treaties and custom, but also as a 'subsidiary means' for determining international law, 'judicial decisions and the teachings of the most highly qualified publicists of the various nations' (ICJ, 2007b, art. 38.1.c-d).

Like all forms of 'higher law', the norms of jus cogens are best seen as fundamentally moral precepts governing individual and institutional conduct in politics, domestic and international. To become jus cogens, these norms must be recognized by states (they would not have much practical effect, in a world of still-sovereign states, if they were not: indeed, a norm typically becomes jus cogens only after a treaty on the subject has been negotiated and ratified by a great many states). But state acceptance is not what makes these moral precepts right; it is merely what makes them law. Determining what is the content of a specific treaty or rule of customary international law might properly be the peculiar province of states, international courts or legal scholars. But determining what moral precepts are sufficiently fundamental and universal that they should be classed as jus cogens is not. The content of jus cogens should equally well turn on the views of people in general. Just as moral intuitions help guide our views on ethical behavior in interpersonal settings, the considered opinions of individuals regarding acceptable behavior by states, international organizations or other global actors should play a part in determining the limits that core international law should be thought to place on those actors.

Our proposal is, quite simply, to add one more item to the standard list of 'subsidiary means' for determining what should be included in jus cogens: ask the people of the world what they think about it. This inquiry flows from the connection between jus cogens and some sense of an international consensus on moral behavior. We do not propose supplanting the existing machinery for determining jus cogens. Rather, we merely propose adding a deliberatively democratic component alongside all the rest. As one additional 'subsidiary means' of determining international law, it is in itself no more conclusive than any of those others. At the same time, because that input is fundamentally different from the others, it might be a useful tie-breaker. ${ }^{1}$

Some states of a particularly autocratic or autarkic bent might not be much impressed by the deliverances of these new directly deliberatively democratic forums. So too might some states not be particularly impressed 
with the existing subsidiary means of identifying jus cogens; they might think some courts or some jurists are not good guides. And some states might refuse to accept any particular norm (or any norms at all) as jus cogens altogether. No matter. Jus cogens is based not on the consent of every state but rather a consensus among the vast majority of states. Unlike treaties or even customary international law, where a state can exempt itself by persistently objecting to the norm as it is being established, a norm of jus cogens legally binds all states whether or not any particular state accepts it.

There are many possible ways of getting democratic input into global decisions. One would be through elected representatives. Another would be through sample surveys. Yet another would be through the representations of civil society organizations. Each of those has its place, but none is ideally suited to the case at hand. All in one way or another presuppose that the public at large already has well-formed and tolerably settled opinions on the subjects under discussion. As regards the optimal content of international law, that is simply not the case.

Furthermore, letting ordinary people from different nations talk it through directly among themselves is more directly democratic than discussions purely through their elected officials or diplomats. Democracy is intrinsically interactional. Your agent talking to my agent is importantly different from (because it involves barriers and filters not found in) my talking to you directly. It may turn out that people talking directly about these things do not come up with anything importantly different from what their representatives would have done, in which case this mechanism would prove redundant. But that must be proven from experience, not assumed in advance of any actual experiment.

In recent years deliberative democrats have perfected techniques suitable for eliciting people's opinion in such circumstances. Specific designs vary (cf. Fung, 2003b; Gastil and Levine, 2005; Goodin and Dryzek, 2006; Smith, 2009). In principle any of many other designs could equally well be employed instead, or in addition. Here however we will focus upon the simplest microdeliberative design: that of a 'Global Citizens' Jury' composed of around 20 people, drawn from around the world. Our proposal is to convene many (perhaps as many as 20) such Global Citizens' Juries simultaneously. In such a 20-by-20 design, juries will be serving as de facto control groups for one another, ensuring that the results are not unduly influenced by one particular jury being hijacked by some charismatic personality or conversational quirks. Each jury should be internally diverse in terms of countries and cultures from which participants are drawn. And all of those juries would be charged with the task of deliberating on the same candidate principle of jus cogens. ${ }^{2}$
That distinctive subject matter on which Global Citizens' Juries would be deliberating, and the distinctive claim that citizens of the world have to speak with some authority on that matter, is what sets our proposal apart from various others. Of course, it is always good to get people's deliberatively considered views on any issue: European integration, immigration and climate change (EuroPolis, 2009); international labor standards (Fung, 2003a); environmental regulations (Baber and Bartlett, 2009); regulation of international trade in toxic wastes (Dryzek et al., 2011, p. 34); and so on. But without further incorporation into formal political decision-making processes, those deliberations can at most inform us what law should be - not what law is. A random sample of ordinary citizens is not empowered to make a treaty, or even to pronounce with any authority on the actual (as opposed to the desired) content of customary international law (cf. Baber and Bartlett, 2009). But in so far as jus cogens norms are supposed to represent the settled views of humanity as a whole on matters of fundamental morality and public policy, a random sample of ordinary citizens should be able to speak to that issue with some authority.

In the composition of the Global Citizens' Jury, diversity matters more than representativeness. The whole point is to discover what common ground there is among all peoples of the world. For that, it is important to get many different perspectives represented; it is not particularly important to get them represented in exactly the same proportion as in the population of the world as a whole (Dryzek and Niemeyer, 2008). ${ }^{3}$ It is a consensus among positions, not a vote of the people, that would justify deeming that something should be regarded as a 'peremptory norm of general international law'.

Ideally members of the Global Citizens' Juries should be randomly selected from among all the people of the world, stratified in such a way as to maximize diversity. Alternatively, we could convene sets of regional meetings or ones designed to hold constant certain key features within each group (such as religion, liberal values, Global North or South, and so on). In practice, a certain element of self-selection always creeps in, as invitees agree or decline to participate. Still, the Global Citizens' Juries will be less purely self-selecting than other mechanisms (such as People's Tribunals or the International Commission of Jurists Open Forums) for involving the public in international lawmaking (Chinkin, 2001). ${ }^{4}$ Jurors could be paid a sitting fee or not, depending on which seems less likely to produce a biased sample of jurors depending on the topic of the deliberation.

One opportunistic recruitment strategy might be to piggyback on world fairs or international sporting events that people from many countries and cultures would already be attending. That could reduce what would be 
the otherwise considerable costs of assembling the jury. Obviously, it would also bias the sample in favor of those who can afford world travel. But that would matter for purposes of the deliberation only if the rich have systematically different opinions from the poor on the specific issue under discussion. With some candidates for principles of jus cogens they may; with others they may not. For deliberations on those where opinions would systematically differ, some other mechanism for funding the juries would have to be found.

The target of the deliberation - those 'candidate principles of jus cogens' - would be identified in the same way jus cogens norms are identified at international law today. Looking at the same sources of law (treaties and conventions, judicial opinions, 'the teachings of the most highly qualified publicists of the various nations'), organizers of the deliberations would identify principles that seem to have a reasonable amount of support already, without having so much as to make further discussion superfluous.

To validate the procedure, however, organizers might in the very first instance ask some Global Citizens' Juries to deliberate on some principle that is already generally accepted as part of jus cogens at present - purely to make sure that the Global Citizens' Juries would indeed 'get the right answer' on matters where there is a reasonably settled view among international lawyers as to what is the right answer. If they do not get the right answer - when on the basis of the various other equally important sources of jus cogens we are as certain as we can be that there is a right answer (imagine a group that opposed banning slavery or torture) - then this mechanism should simply be abandoned as a failure.

Briefing papers would be prepared by a panel of experts, balanced so as to represent all the major perspectives on the issue. (Because these are candidate principles about which there is still some controversy, spokespersons for various positions could easily be found.) Those papers would be circulated to jury members before the meeting. Meetings would be convened in one physical location with a facilitator present to ensure respectful dialogue. In later iterations, online conferencing might be substituted (Grönlund, 2009), but in the first instance face to face is probably to be preferred.

The jury would have a preliminary get-to-know-oneanother meeting the first afternoon, where procedures and background on the issue are discussed. The next day or two, the exact length depending on the complexities of the issue, would be given over to testimony from experts, and questioning of the experts by the jury members. (The experts would include but rarely be limited to lawyers: experts from other fields may have useful information regarding the possible consequences of accepting a norm as a peremptory norm of international conduct.) The final day or two would be devoted to discussion within the jury itself, aimed at coming to a decision as to whether or not the candidate principle should indeed be recognized as jus cogens.

Ideally a decisive recommendation would emerge from each jury, the same as from all others. But if it turns out that even after careful deliberation opinion is split within or across juries, that in itself is relevant to determining whether the proposition really does command the general assent of people worldwide.

The great benefit of deliberatively democratic designs such as Global Citizens' Juries, as compared to other democratic techniques, is that they evoke considered, informed opinions from people. Participants become better informed as both the direct and indirect result of the exercise. They learn from the briefing materials before the process, from the expert testimony and from one another throughout the process. But in addition to that, people expecting to participate in such an event also pay more attention to information concerning that topic as it comes up in the course of their daily lives, in the news, in conversation and so on. Evidence consistently suggests strong information gains among those participating in such micro-deliberative events (Luskin et al., 2002).

There is also considerable evidence that people's views are 'better ordered' after deliberation than before. Even where people still disagree at the end of the day, at least they 'agree what they disagree about'. They are no longer 'talking past one another'. They see the broad outlines - the basic dimensions - of the issue in the same way, even if they still take different sides on it (Dryzek and Niemeyer, 2006; List et al., 2009).

Finally, considerable evidence suggests that these effects are robust to the passage of time. When participants in micro-deliberative events are re-interviewed months afterwards, their information base and their views remain substantially unchanged. Deliberation produces views that are 'settled' in a way that those reported in sample surveys often are not, representing instead top-of-the-head responses showing 'nonattitudes' (Converse, 1964, 1970) that are unstable over time.

All of these features combine to make micro-deliberative designs highly appropriate for democratically evoking the opinions of people on questions, like the optimal content of international law, upon which people have not previously had much occasion to reflect. Wellorganized and well-moderated micro-deliberative events evoke opinions that are informed, coherent and settled. In so far as those opinions differ (and often they do) from those that participants might unreflectively have held prior to the deliberation, post-deliberative opinions should be democratically preferred as participants' own more considered opinions. And when (as not 
infrequently happens) opinion changes consistently in the same direction across the great bulk of deliberators, there is reason to suppose that the opinions of the public at large would have shifted similarly if they had also been given the opportunity to deliberate properly on the matter (Dahl, 1989, p. 342; Fishkin, 2003). Thus, the deliberations of Global Citizens' Juries can be democratically informative, even if members of the juries strictly speaking 'represent no one except themselves'.

For precisely these reasons, micro-deliberative designs are increasingly used to guide public policy making across a range of settings. Occasionally the deliberating group is literally empowered to determine public policy on some issue. One example comes from China, where 'the Zeguo Town leadership made - and carried through on - an explicit commitment to fund the [infrastructure] projects [that participants in a Deliberative Poll] rated highest after deliberating' (Fishkin et al., 2010, p. 437). Another example is the way in which resource allocation decisions are discursively determined through democratic meetings in Indian villages, gram sabhas (Rao and Sanya, 2010). ${ }^{5}$ Yet another example comes from Canada, where the British Columbia Citizens' Assembly was charged with crafting a proposal for electoral reform which the government promised in advance to put to referendum (Warren and Pearce, 2008).

More typically, micro-deliberations play an advisory role. They have been heavily employed in this way in the UK for everything from priority setting in health care (Cooper et al., 1995; Lenaghan et al., 1996; Parkinson, 2006) to policy making on genetically modified foods (Heller, 2004). They have been used by the Danish Board of Technology to inform the parliament on 'legislation limiting the use of genetic screening in hiring and insurance decisions, to exclude genetically modified animals from the government's initial biotechnology research and development program, and to prohibit food irradiation for everything except dry spices' (Sclove, 2011). They have been used by the Public Utility Commission of Texas to advise on alternative strategies for sourcing electricity (Fishkin, 2003; Lehr et al., 2003). They have been used to advise on designs for rebuilding on the site of the World Trade Center in New York (Fung and Rosegrant, 2006).

Perhaps the most pervasive function of these more purely advisory micro-deliberations has been as a sort of political market testing. Policy makers formally charged with responsibility for making the decision are informed by these deliberatively democratic micro forums whether the proposals they are contemplating could garner general public support, even if people had a chance to hear all the evidence and reflect and discuss it carefully. If not - as was clearly the case with the initial design for the World Trade Center rebuilding or with proposals for genetically modified crops in the UK - then policy makers back off those proposals in response.

That is precisely the role here being envisaged for Global Citizens' Juries in helping to determine norms of jus cogens. Traditional 'sources' of jus cogens do not literally constitute jus cogens. Instead, they are sources of information on what moral precepts states, courts and scholars think are sufficiently universal and important to count as peremptory norms of international conduct. So too the Global Citizens' Juries would be a source of information on what moral precepts individuals around the world consider are sufficiently universal and important to be regarded in that way.

Once the Global Citizens' Juries' deliberations are completed, what is the best way to incorporate their inputs into the processes by which candidate norms get accepted by the world community as jus cogens? International law lacks any simple procedure for taking account of the 'subsidiary means' of identifying norms. Norms can bubble up and spread through the efforts of 'norm entrepreneurs' (Finnemore and Sikkink, 1998). Groups of 'eminent persons' worldwide can start advocating the cause. A few state actors start talking about the norm in question as being jus cogens. More states hop on the bandwagon. Late in the day, some courts do likewise. International law has repeatedly come in just such ways to accept new norms, ranging from the ban on slavery, to the illegality of aggressive war, to the duty to prevent impunity for genocide and crimes against humanity. We would expect the results of Global Citizens' Juries to be picked up in much the same way as scholarly articles or influential speeches from important dignitaries currently are in this process.

Conveners of a Global Citizens' Jury could get that process started by drawing the results of that jury to the attention of global decision makers, using various authoritative 'mailboxes' already available within the UN system. Conveners of a Global Citizens' Jury could, for example, get a friendly state to circulate the report of its results as an official document of the UN General Assembly or Human Rights Council. Beyond the UN, they could send the report to the Secretaries General of the Organization of American States (OAS), the Council of Europe, the African Union, the Association of Southeast Asian Nations (ASEAN) and so on, for distribution to their members.

Some commentators would demur from our proposal. Those who persistently prefer to give priority to national over international law might say that there is something ironic about democratizing jus cogens. The whole point of jus cogens, they would emphasize, is to limit a state's freedom of action - which, if it is a democratic state, means limiting the ways in which the democratic will of the people in that state can be implemented. However 'democratic' we make jus cogens (unless we limit our 
juries to a purely domestic audience, thereby defeating the whole purpose of our proposal), they would say, the whole point of jus cogens is to limit the power of domestic democratic majorities (Rabkin, 2005).

Domestically, however, it is well understood that the rule of law is part of what it means for a state to be democratic. Indeed, on some accounts, these constraints are literally constitutive of democracy (Brettschneider, 2007; Christiano, 2008; Ely, 1980; Holmes, 1995, ch. 4). There are certain things that constitutional democracies simply cannot do, because they violate rights and other fundamental principles entrenched in constitutional or international law. It is a matter of democratic principle that majorities should be restricted in precisely these ways.

Internationally, too, there are certain things that democratic majorities should not be allowed to do to other states and their residents. Incontrovertibly, a democratic majority in one state should not be able to violate a solemn treaty commitment that that state has made to another state, just because it decides that it does not like the treaty or the other state any more. The idea of jus cogens goes beyond that, expressing the concept that there are some norms that even a democratic majority of individuals in one state, or even a group of states acting together, whether through a law, treaty or policy, should never be able to violate. The reason, internationally as well as domestically, is that those norms evoke the same foundational principles as those on which democracy is built, namely principles of human dignity and equality.

From the other direction, some might oppose our proposal by insisting that jus cogens norms, as a reflection of international morality, should not be the subject of democratic deliberation - or even state preferences - at all. This view effectively contests the accepted meaning of jus cogens - norms accepted by the 'international community of States as a whole' (Vienna Convention on the Law of Treaties, 1969, art. 53) - and seeks to replace it with some higher law pronounced by philosophers, theologians, international lawyers or God. But leaving these determinations to those supposed authorities seems a recipe for paralysis. More important, it would produce those norms though a process that states and other international actors - whom jus cogens seeks to bind - will find illegitimate and ultimately irrelevant.

Democratizing international law in the way we propose would involve asking the people of the world, and not just their governments, their general understanding of those fundamental principles. At root, states are mere agents of their people. Ascertaining people's own views, in some suitable fashion that is both deliberative and democratic, might be a valuable aid in securing broader legitimacy and general acceptance of these most basic rules of international law and the constraints and demands that they place on democratic majorities.
UN Secretary-General Annan (2006) was fond of quoting President Truman's (1945) remarks in the closing session of the San Francisco convention founding the United Nations: 'We all have to recognize - no matter how great our strength - that we must deny ourselves the license to do always as we please'. If we are going to get national democratic majorities to accept that basic rules of international law should limit them in this way, it is only prudent to allow some democratic input of the sort we have suggested into the determination of that international law in the first place.

\section{Notes}

We are grateful for discussion of these issues with Liz Anderson, André Bächtiger, Christian Barry, Eyal Benvenisti, Andrea Bianchi, Hilary Charlesworth, Christine Chinkin, John Dryzek, Archon Fung, Seth Lazar, Jenny Mansbridge, Larry May, Karolina Milewicz, David Miller, Andreas Paulus, Roland Rich, Adrian Vermeule, David Wippman, Lea Ypi and editors and referees of this journal. We alone are to blame for the final product.

1. Baber and Bartlett (2009) propose international citizens' juries be used to inform customary international law, particularly on environmental matters. We wonder how such views would help determine the customary practices of the community of states. But because of the close connection between jus cogens and notions of international morality, it is especially appropriate to involve ordinary people in identifying jus cogens.

2. The main example so far of a directly deliberative event involving citizens of different countries was the EU-wide EuroPolis conducted in May 2009, according to a slightly different design; see http://www.europolis-project.eu. There are parallel proposals for cross-national, deliberatively democratic panels developing lower-level rules, such as international labor standards; see Fung, 2003a.

3. It is impossible, in any case, to get a remotely representative sample of any large and heterogeneous population using a group that is small enough genuinely to deliberate together (whether of 20 people or a few hundred).

4. They will also be more concerned with establishing principles rather than prosecuting particular cases, as is typically the case with People's Tribunals. See, e.g., Chinkin, 2001.

5. The famous Participatory Budgeting process in Porto Alegre, Brazil, is slightly different, in using directly deliberative designs to develop mandates for representatives then elected to meet and make budgetary decisions among themselves; Baiocchi, 2001.

\section{References}

Annan, K. (2006) 'Speech at the Truman Library, 11 December 2006'. Available from: http://www.un.org/News/ossg/sg/stories/ statments_full.asp?statID $=40$ [Accessed 24 May 2011].

Baber, W. F. and Bartlett, R. V. (2009) Global Democracy and Sustainable Jurisprudence: Deliberative Environmental Law. Cambridge, MA: MIT Press.

Baiocchi, G. (2001) 'Participation, Activism and Politics: The Porto Alegre Experiment and Deliberative Democratic Theory', Politics \& Society, 29 (1), pp. 43-72.

Boyle, A. and Chinkin, C. (2007) The Making of International Law. New York: Oxford University Press. 
Brettschneider, C. (2007) Democratic Rights. Princeton, NJ: Princeton University Press.

Chinkin, C. (2001) 'Women's International Tribunal on Japanese Military Sexual Slavery', American Journal of International Law, 95 (2), pp. 335-341.

Christiano, T. (2008) The Constitution of Equality: Democratic Authority and Its Limits. Oxford: Oxford University Press.

Converse, P. E. (1964) 'The Nature of Belief Systems in Mass Publics', in D. E. Apter (ed.), Ideology and Discontent. New York: Free Press, pp. 206-261.

Converse, P. E. (1970) 'Attitudes and Nonattitudes: Continuation of a Dialogue', in E. R. Tufte (ed.), The Quantitative Analysis of Social Problems. Reading, MA: Addison-Wesley, pp. 168-189.

Cooper, L., Coote, A., Davies, A. and Jackson, C. (1995) Voices Off: Tackling the Democratic Deficit in Health. London: Institute for Public Policy Research.

Dahl, R. A. (1989) Democracy \& Its Critics. New Haven, CT: Yale University Press.

Dryzek, J. S., Bächtiger, A. and Milewicz, K. (2011) 'Toward a Deliberative Global Citizens' Assembly', Global Policy, 2 (1), pp. 33-42.

Dryzek, J. S. and Niemeyer, S. (2006) 'Reconciling Pluralism and Consensus as Political Ideals', American Journal of Political Science, 50 (3), pp. 634-649.

Dryzek, J. S. and Niemeyer, S. (2008) 'Discursive Representation', American Political Science Review, 102 (4), pp. 481-494.

Ely, J. H. (1980) Democracy \& Distrust. Cambridge, MA: Harvard University Press.

EuroPolis (2009) 'A Deliberative Polity-Making Project' [online]. Available from: http://www.europolis-project.eu [Accessed 24 May 2011].

Finnemore, M. and Sikkink, K. (1998) 'International Norm Dynamics and Political Change', International Organization, 52 (4), pp. 887-917.

Fishkin, J. S. (2003) 'Consulting the Public through Deliberative Polling', Journal of Policy Analysis and Management, 22 (1), pp. 128-133.

Fishkin, J. S., He, B., Luskin, R. C. and Siu, A. (2010) 'Deliberative Democracy in an Unlikely Place: Deliberative Polling in China', British Journal of Political Science, 40 (2), pp. 435-448.

Frowein, J. (2008) 'Obligations Erga Omnes', Max Planck Encyclopedia of Public International Law [online]. Available from: http://www. mpepil.com [Accessed 24 May 2011].

Fung, A. (2003a) 'Deliberative Democracy and International Labor Standards', Governance, 16 (1), pp. 51-71.

Fung, A. (2003b) 'Recipes for Public Spheres: Eight Institutional Choices and Their Consequences', Journal of Political Philosophy, 11 (3), pp. 338-367.

Fung, A. and Rosegrant, S. (2006) 'Listening to the City: What Should be Built at Ground Zero?' in A. Gutmann and D. Thompson (eds.), Ethics and Politics: Cases and Comments, fourth edition. Belmont, CA: Thomson Wadsworth, pp. 303-310.

Gastil, J. and Levine, P. (eds) (2005) The Deliberative Democracy Handbook. San Francisco, CA: Jossey-Bass.

Goodin, R. E. and Dryzek, J. S. (2006) 'Deliberative Impacts: The Macro-political Uptake of Mini-publics', Politics \& Society, 34 (2), pp. 219-244.

Grönlund, K. (2009) 'The Challenge of Deliberative Democracy Online: A Comparison of Face-to-Face and Virtual Experiments in Citizen Participation', Information Polity, 14 (3), pp. 187-201.

Heller, R. (2004) GM Nation? The Findings of the Public Debate. London: GM Public Debate Steering Board. Available from: http://www.gmnation.org.uk?ut_09/ut_9_6.htm [Accessed 24 May 2011].

Holmes, S. (1995) Passions and Constraint. Chicago, IL: University of Chicago Press.
International Court of Justice (ICJ) (2007a) 'Application of the Convention on the Prevention and Punishment of the Crime of Genocide (Bosnia and Herzegovina v. Serbia and Montenegro)', Judgment of 26 February 2007. Available from: http://www. icj-cij.org [Accessed 24 May 2011].

International Court of Justice (ICJ) (2007b) Statute of the International Court of Justice. Available from: http://www.icj-cij.org/documents/index.php?p1 = 4\&p2 = 2\&p3 =0 [Accessed 24 May 2011].

Lehr, R. L., Guild, W., Thomas, D. L. and Swezey, B. G. (2003) Listening to Customers: How Deliberative Polling Helped Build 1000 MW of New Renewable Energy Projects in Texas. Technical Report NREL/TP-620-33177. Golden CO: National Renewable Energy Laboratory.

Lenaghan, J., New, B. and Mitchell, E. (1996) 'Setting Priorities: Is There a Role for Citizens' Juries?' British Medical Journal, 312 (7046), pp. 1591-1594.

List, C., Luskin, R. C., Fishkin, J. S. and McLean, I. (2009) 'Deliberation, Single-Peakedness, and the Possibility of Meaningful Democracy: Evidence from Deliberative Polls'. Working Paper, London School of Economics, 2 November. Available from: http://personal. Ise.ac.uk/list/PDF-files/DeliberationPaper.pdf [Accessed 24 May 2011].

Luskin, R. C., Fishkin, J. S. and Jowell, R. (2002) 'Considered Opinions: Deliberative Polling in Britain', British Journal of Political Science, 32 (3), pp. 455-488.

Parkinson, J. (2006) Deliberating in the Real World. Oxford: Oxford University Press.

Rabkin, J. A. (2005) Law without Nations? Why Constitutional Government Requires Sovereign States. Princeton, NJ: Princeton University Press.

Rao, V. and Sanya, P. (2010) 'Dignity through Discourse: Poverty and the Culture of Deliberation in Indian Village Democracies', Annals of the American Academy of Political \& Social Science, 629, pp. 146-172.

Raustiala, K. (1997) 'States, NGOs, and International Environmental Institutions', International Studies Quarterly, 41 (4), pp. 719-740.

Sclove, R. E. (2011) 'Town Meetings on Technology: Consensus Conferences' [online]. Available from: http://www.loka.org/pubs/ techrev.htm [Accessed 24 May 2011].

Simma, B. (1994) 'From Bilateralism to Community Interest in International Law', Recueil des Cours, 250, pp. 217-387.

Smith, G. (2009) Democratic Innovations. Cambridge: Cambridge University Press.

Truman, H. S. (1945) 'Address in San Francisco at the Closing Session of the United Nations Conference, June 26th, 1945'. Available from: http://www.presidency.ucsb.edu/ws/index.php? pid=12188 [Accessed 24 May 2011].

Verdross, A. (1937) 'Forbidden Treaties in International Law', American Journal of International Law, 31 (4), pp. 571-577.

Vienna Convention on the Law of Treaties (1969) Available from: http://untreaty.un.org/ilc/texts/instruments/english/conventions/ 1_1_1969.pdf [Accessed 24 May 2011].

Warren, M. and Pearce, H. (eds) (2008) Designing Deliberative Democracy: The British Columbia Citizens' Assembly. Cambridge: Cambridge University Press.

\section{Author Information}

Professor Robert E. Goodin, School of Philosophy, Research School of Social Sciences, Australian National University, and Department of Government, University of Essex.

Professor Steven R. Ratner, Law School, University of Michigan. 